\title{
The interpretative significance of ripple-derived sedimentary structures within an upper Neogene fluvial succession of central Poland
}

\author{
Piotr Maciaszek ${ }^{1}$, Lilianna Chomiak ${ }^{1}$, Robert Wachocki ${ }^{2}$, Marek Widera ${ }^{1 *}$ \\ ${ }^{1}$ Institute of Geology, Adam Mickiewicz University, Krygowski 12, 61-680 Poznań, Poland; \\ ${ }^{2}$ Konin Lignite Mine; 600-lecia 9, 62-540 Kleczew, Poland; \\ *corresponding author, e-mail: widera@amu.edu.pl
}

\begin{abstract}
Sedimentary structures discussed in the present study are genetically linked to ripples that consist of pure sand or alternating sand and mud layers. All types of ripple-related structures, such as climbing-ripple cross-lamination and heterolithic bedding, i.e., flaser, wavy and lenticular (nodular), have been identified for the first time in fluvial strata that have been characterised previously as commonly massive. These small-scale bedforms, produced by migrating ripples, have been documented in a fluvial channel of late Neogene age in central Poland. The abundance and co-occurrence of the structures discussed and their spatial distribution provide evidence of their formation under very low-energy conditions, when flow velocity changed markedly, but was often significantly less than $0.5 \mathrm{~m} / \mathrm{s}$. Therefore, these ripple-derived sedimentary structures are here recognised as typical of channel fills of an anastomosing river.
\end{abstract}

Key words: sedimentology, depositional structures, ripples, anastomosing river

\section{Introduction}

Ripples belong to small-scale bedforms that arise under lower flow regime conditions. In general, their height ranges from 0.3 to $6 \mathrm{~cm}$ and their length is in the range of 4-60 cm (Reineck \& Singh, 1980; Ashley, 1990). They may be symmetrical or asymmetrical. In the latter case, the stoss slope angle is relatively gentle in comparison to the lee slope angle, which is close to the angle of repose $\left(25-30^{\circ}\right)$ for that saturated with water and the sand and coarsegrained silt particles are $0.02-0.7 \mathrm{~mm}$ in size building these ripples. These small-scale bedforms are very diverse in their plan form. This is due to the fact that the first ones created were 2D ripples with straight crests, which together with the increasing flow velocity, are transformed into 3D ones with curved crests (e.g., Allen, 1968; Collinson, 1970; Blatt et al., 1980; Reineck \& Singh, 1980; La Croix \& Dashtgard, 2015; Baas et al., 2016).

Sandy current ripples are very common in most depositional environments (Allen, 1968; Hunter, 1977; Blatt et al., 1980; Zieliński \& Van Loon, 2000; Gruszka, 2001; Hadlari et al., 2006; Gruszka et al., 2012; Allen et al., 2013; Pawłowski et al., 2013; Zieliński, 2014; Kędzior, 2016; and references therein). The ripple cross-lamination indicates only that the water flow was unidirectional for current ripples and flow velocity was less than $1 \mathrm{~m} / \mathrm{s}$ (Ashley, 1990). In the case of fine sand $(0.063-0.25 \mathrm{~mm})$, however, current ripples develop at a flow velocity of $<0.5 \mathrm{~m} / \mathrm{s}$ (Baas, 1999). Conversely, other types of small-scale cross-lamination that are produced by moving ripples, made of alternating sandy and 
muddy laminae, are much more interesting as far as their origin is concerned. These specific sedimentary structures are as follows: climbing-ripple cross-lamination, flaser, wavy and lenticular bedding. They are attributed to fluctuations in flow strength, variations in grain size of fine-grained sediments and concentration of suspended particles in flowing to near-stagnant water (e.g., Reineck \& Wunderlich, 1968; Środon, 1974; Ashley et al., 1982; Ashley, 1990; Yokokawa et al., 1995; Martin, 2000; Dalrymple, 2010; Fan, 2013; Zieliński, 2014; Kędzior, 2016), or may depend on the configuration of the depositional surface (Pasierbiewicz, 1982).

Until now, ripple cross-lamination was documented only occasionally within channel-filled deposits that represent an anastomosing river system of late Neogene age in central Poland (Widera et al., 2017). Other specific sedimentary structures, i.e., climbing-ripple cross-lamination and heterolithic bedding (flaser, wavy and lenticular), genetically associated with ripples, are described for the first time in the present paper. Therefore, the major goals of this research are twofold: to document ripple-related sedimentary structures from the palaeochannel of an anastomosing river and to provide evidence of their interpretative significance in term of flow conditions.

\section{Geological setting}

The channel-filled deposits studied outcrop in the Jóźwin IIB lignite opencast area. This territory covers the northernmost part of the relatively shallow Kleczew Graben, which is situated $10-20 \mathrm{~km}$ north of Konin in central Poland (Fig. 1). The tectonic depression, with Cretaceous limestones at their base, is filled with Neogene and Quaternary deposits. It is worth noting that the entire Paleogene and a significant part of the Pliocene-Pleistocene are covered by stratigraphical gaps (Fig. 2), related to tectonic uplift where erosion prevailed over deposition (Widera, 2007, 2014).

The Cenozoic evolution of the Kleczew Graben began at the Paleogene/Neogene transition. The Koźmin Formation (earliest to middle Miocene), the oldest lithostratigraphical unit, is up to a few tens of metres thick and consists of fluvio-lacustrine sand and silt deposits with lignite intercalations. Strata of the overlying Poznań Formation (late middle Miocene to earliest Pliocene) have traditionally been subdivided into two members, i.e., the lower Grey Clays Member (also termed the Mid-Polish Member) and the upper Wielkopolska Member (Piwocki \& Ziembińska-Tworzydło, 1997; Widera, 2007, 2013) (compare Figs. 1C, 2).
The lignite-rich Grey Clays Member comprises mostly the first Mid-Polish lignite seam (MPLS-1), with siliciclastic intercalations, which is currently exploited by the Konin Lignite Mine. This lignite seam covers the middle part of the middle Miocene in age ( 15 Ma) (Kasiński \& Słodkowska, 2016; Widera et al., 2017), and has an average thickness of $6.6 \mathrm{~m}$. It is currently assumed that the accumulation of peat, which then transformed into MPLS-1, took place in low-lying mires in the overbank zone of the middle Miocene fluvial system (Widera, 2016a, b). Overlying is the mud-dominated Wielkopolska Member, with fluvial channel-fill deposits; the subject of the present research (compare Figs. 1B-E, 2). In the study area, the total thickness of the Wielkopolska Member changes from a few metres to more than $20 \mathrm{~m}$, and the maximum thickness of in-channel sediments attains 5-9 m. The fine-grained deposits (muds) are attributed to the overbank area, while the succession examined is attributed to the channel zone of middle Miocene-earliest Pliocene $(<13.5$ Ma) anastomosing river system in central Poland (Widera, 2013; Widera et al., 2017).

The Quaternary cover, with an average thickness of 40-50 m, overlies the Neogene succession (compare Figs. 1C, 2). These deposits are mainly of glaciogenic origin and include glacial tills, fluvioglacial gravels and sands, as well as glaciolacustrine muds and sandy muds (Widera, 2014; Widera et al., 2017).

\section{Methods}

In the opencast mines, exploited by the Konin Lignite Mine, a few dozens of fluvial palaeochannels within the Wielkopolska Member have been documented. Sediments filling these were characterised by their common massiveness (Widera, 2012, 2013; Widera et al., 2017). In contrast, the palaeochannel that outcropped in 2017 at the Jóźwin IIB lignite opencast mine (Fig. 1D, E), contained a large number of sedimentary structures. During fieldwork, observations and descriptions have been made of small-scale structures that are associated with ripples (Figs. 3-7). Additionally, 27 palaeocurrent measurements were made and 35 samples were collected for laboratory grain-size analyses.

The elongation (strike) of the palaeochannel measured in the summer/autumn of 2017 was 110 $290^{\circ}$ with a depth of $9 \mathrm{~m}$ and a width of $150 \mathrm{~m}$ in a southerly-northerly direction. The recalculated true width was $\sim 140 \mathrm{~m}$. The examined ripple-related sedimentary structures were observed in the axial zone of the palaeochannel at about 2.3-2.6, 3.4-4.2 and 6.4-6.8 $\mathrm{m}$ above its base (Fig. 1D). 
In the present study, the standard grain-size scale is used. According to the field classification of fine-grained deposits mud is defined as a sediment containing $>50$ volume percentage of clay and silt
(Lundegard \& Samuels, 1980). The sediment denominators were subsequently improved according to details from laboratory analyses. A conventional sieving technique has been used for sandy, non-co-
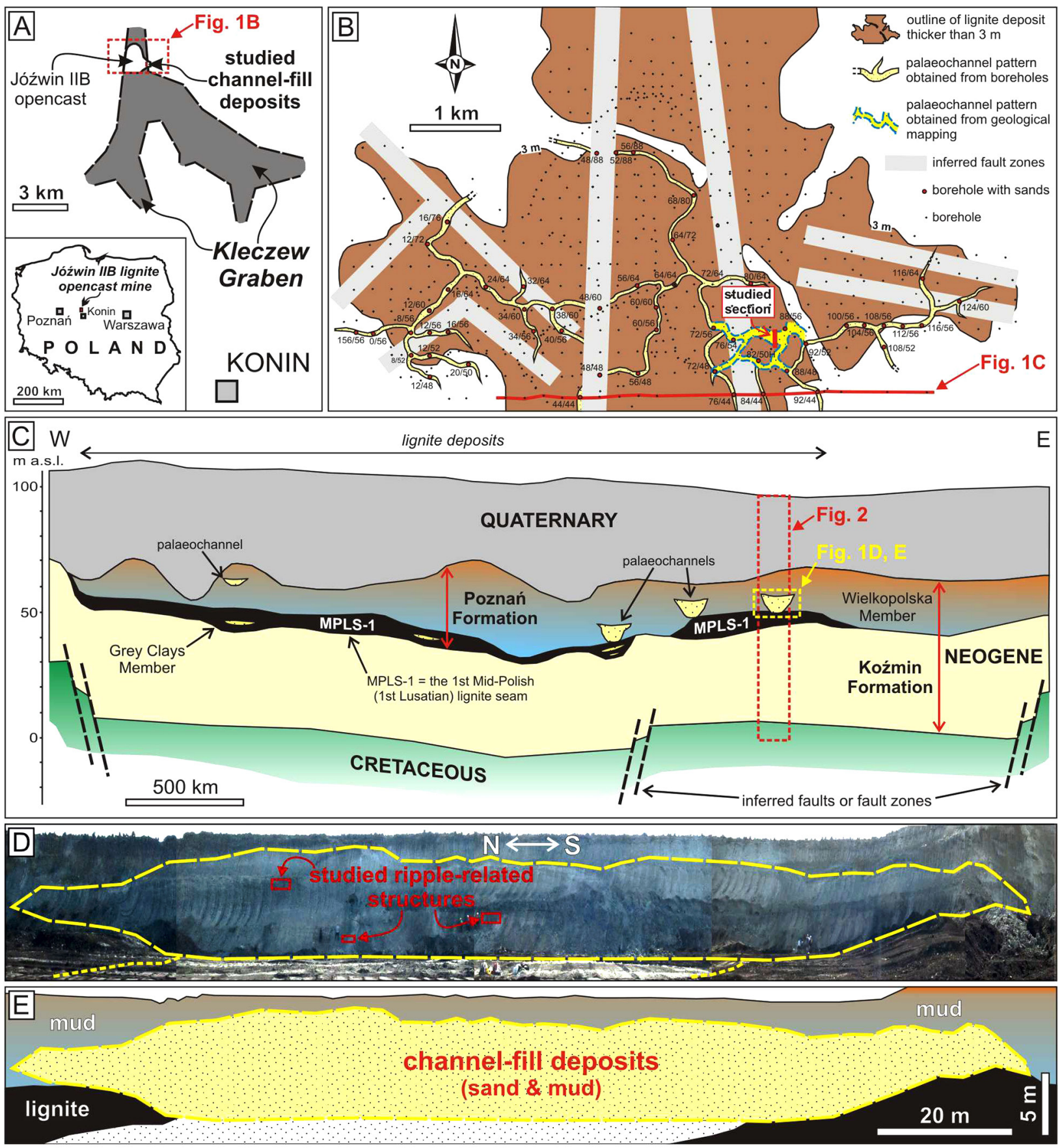

Fig. 1. Locality map and geology of the study area. A - Map of the Konin area in central Poland showing the location of the Jóźwin IIB lignite opencast mine in the Kleczew Graben area; B - Palaeochannel pattern inferred from borehole data and geological mapping in the area of the Pątnów IV lignite deposits (modified from Widera et al., 2017); C - Simplified geological cross-section through the northern segment of the Kleczew Graben (the southernmost part of the Pątnów IV lignite deposits) with the approximate stratigraphical position of the palaeochannel studied (modified from Widera, 2014, Widera et al., 2017); D, E - Broad view and corresponding line-drawings of the palaeochannel. Note the location of the ripple-related structures within the palaeochannel examined 


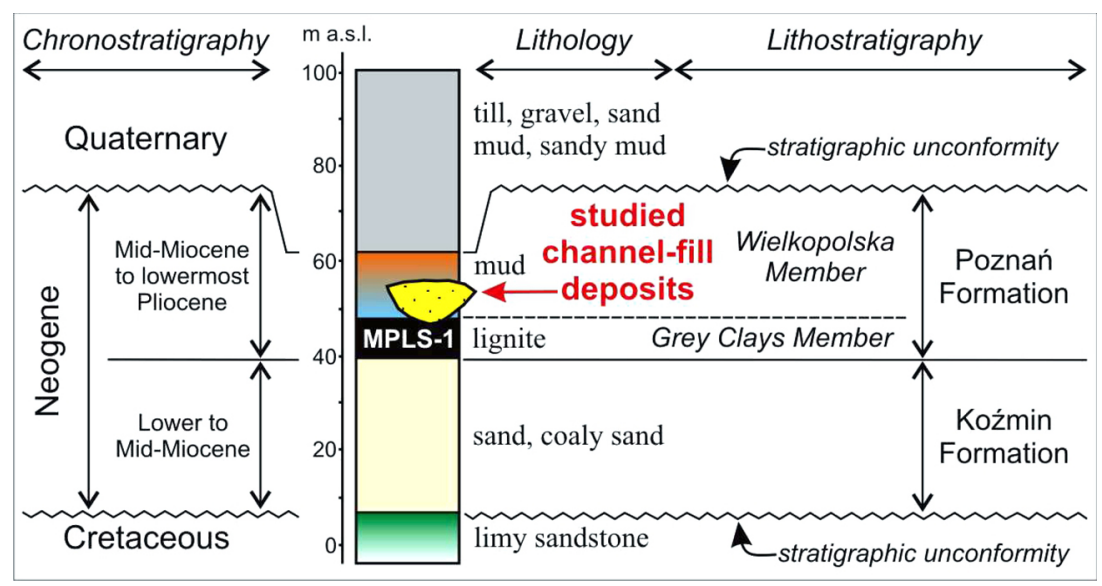

Fig. 2. Stratigraphical sketch of the Cenozoic succession within the Kleczew Graben (modified from Widera, 2007, 2014). Note the stratigraphical position of the examined channel-fill deposits within the muddy Wielkopolska Member of late Neogene age; MPLS-1 - the First Mid-Polish lignite seam; for approximate position of the lithological section see Figure 1C

Table 1. Selected lithofacies associations occurring within the channel-fill deposits that represent a late Neogene anastomosing river system in central Poland

\begin{tabular}{|c|c|c|c|c|}
\hline $\begin{array}{l}\text { Lithofacies } \\
\text { association }\end{array}$ & Code & Lithofacies & Occurrence \& description & Interpretation \\
\hline $\begin{array}{l}\text { Lithofacies } \\
\text { association } \\
\text { of horizon- } \\
\text { tal lamina- } \\
\text { tion* }\end{array}$ & MSh & $\begin{array}{l}\text { Horizontally } \\
\text { stratified } \\
\text { muddy sand; } \\
\text { horizontally } \\
\text { stratified mud }\end{array}$ & $\begin{array}{l}\text { Various parts of channel-fill, except its } \\
\text { lowermost and uppermost parts. } \\
\text { Relatively the largest lateral extent up to a } \\
\text { few } 10 \text { s m, but only up to } 0.5-2 \mathrm{dm} \text { thick; } \\
\text { with flat depositional or erosional base. }\end{array}$ & $\begin{array}{l}\text { Predominantly tractional deposition } \\
\text { from bedload transport; lower flow } \\
\text { regime without evident erosion of } \\
\text { underlying deposits ripples; sporad- } \\
\text { ically upper flow regime (= erosive } \\
\text { base); water flow too strong for } \\
\text { ripples and too shallow for dunes } \\
\text { formation. }\end{array}$ \\
\hline $\begin{array}{l}\text { Lithofacies } \\
\text { association } \\
\text { of massive } \\
\text { sediments* }\end{array}$ & SMm & $\begin{array}{l}\text { Massive fine- } \\
\text { grained sand; } \\
\text { massive mud- } \\
\text { dy sand }\end{array}$ & $\begin{array}{l}\text { Both lithofacies are common in all parts of } \\
\text { the palaeochannel, especially in its upper } \\
\text { part. } \\
\text { Up to a few dm thick; massive structure; } \\
\text { Sm - low content clay and silt, light grey } \\
\text { in colour; SMm - rich in mud admixture, } \\
\text { grey in colour; Sm and SMm pass often } \\
\text { laterally and vertically to other small-scale } \\
\text { lithofacies. }\end{array}$ & $\begin{array}{l}\text { Hyperconcentrated to tractional } \\
\text { flow; non- to weak tractional dep- } \\
\text { osition of pure sand or/and sand } \\
\text { with a muddy admixture; first, from } \\
\text { dense turbulent suspension, and } \\
\text { then from weak traction by over- } \\
\text { bank floodwater drained back to } \\
\text { palaeochannel; massive structure is } \\
\text { due to well sorting and the lack of } \\
\text { colour contrast; in most cases this } \\
\text { structure was originally rippled. }\end{array}$ \\
\hline $\begin{array}{l}\text { Lithofacies } \\
\text { association } \\
\text { of ripple } \\
\text { cross-lami- } \\
\text { nation* }\end{array}$ & $\mathrm{SMr}$ & $\begin{array}{l}\text { Ripple } \\
\text { cross-laminat- } \\
\text { ed fine sand; } \\
\text { ripple } \\
\text { cross-laminat- } \\
\text { ed silty sand; } \\
\text { ripple } \\
\text { cross-lami- } \\
\text { nated muddy } \\
\text { sand }\end{array}$ & $\begin{array}{l}\text { All parts of the palaeochannel. } \\
\text { Cross-stratified laminae sets are up to 5-6 } \\
\mathrm{cm} \text { thick and co-set thickness reaches 1-3 } \\
\mathrm{dm} \text {; Sr - almost pure sand, white in col- } \\
\text { our; STm - rich in silt, light grey in colour; } \\
\text { SMr - rich in mud (clay and silt), grey } \\
\text { in colour; these lithofacies form separate } \\
\text { beds or co-exist with other small- and } \\
\text { large-scale lithofacies. }\end{array}$ & $\begin{array}{l}\text { Tractional deposition from bedload } \\
\text { transport as small current ripples; } \\
\text { lower part of lower flow regime; this } \\
\text { association is very close to associ- } \\
\text { ation above-described (Sm, SMm), } \\
\text { but tractional transport play here } \\
\text { more significant role. }\end{array}$ \\
\hline $\begin{array}{l}\text { Lithofacies } \\
\text { association } \\
\text { of climb- } \\
\text { ing-ripple } \\
\text { cross-lami- } \\
\text { nation** }\end{array}$ & STrc & $\begin{array}{l}\text { Climbing-rip- } \\
\text { ple cross-lam- } \\
\text { inated fine } \\
\text { sand; } \\
\text { climbing-rip- } \\
\text { ple cross-lam- } \\
\text { inated silty } \\
\text { sand }\end{array}$ & $\begin{array}{l}\text { Both lithofacies occur occasionally in axial } \\
\text { zone of the palaeochannel. } \\
\text { Individual cross-strata laminae sets are } \\
\text { up to } 2.5 \mathrm{~cm} \text { thick; an angle of climb is } \\
<10^{\circ} \text {; bases and tops are erosional; this } \\
\text { association is underlain by lithofacies Sm } \\
\text { and capped by various sandy lithofacies } \\
\text { above an erosional surface; climbing-rip- } \\
\text { ple cross-lamination represents the A-type } \\
\text { ripple. }\end{array}$ & $\begin{array}{l}\text { Predominantly fine sand (Src) and } \\
\text { occasionally a slight admixture of } \\
\text { silt (STrc) is transported both in trac- } \\
\text { tion and suspension; lower part of } \\
\text { lower flow regime; this lamination } \\
\text { is formed during periods of waning } \\
\text { flow }(<0.5 \mathrm{~m} / \mathrm{s} \text { ) in water rich in } \\
\text { suspended, mainly sandy load; the } \\
\text { A-type ripples are created when the } \\
\text { bed-load transport is higher than the } \\
\text { suspended-load transport. }\end{array}$ \\
\hline
\end{tabular}




\begin{tabular}{|c|c|c|c|c|}
\hline $\begin{array}{l}\text { Lithofacies } \\
\text { association }\end{array}$ & Code & Lithofacies & Occurrence \& description & Interpretation \\
\hline \multirow{3}{*}{$\begin{array}{l}\text { Lithofacies } \\
\text { association } \\
\text { of het- } \\
\text { erolithic } \\
\text { bedding** }\end{array}$} & Sf & $\begin{array}{l}\text { Fine sand } \\
\text { with a flaser } \\
\text { bedding; }\end{array}$ & \multirow{3}{*}{$\begin{array}{l}\text { Lithofacies are located in various parts of } \\
\text { the palaeochannel with exception of its the } \\
\text { lower- and uppermost beds. } \\
\text { They build up a few upward-fining cycles } \\
\text { that are } 0.1-0.6 \text { m thick; these lithofacies } \\
\text { are sometimes separated by the erosive } \\
\text { surfaces; flaser bedding consists of con- } \\
\text { cave-up mud lenses, in the muddy-sandy } \\
\text { matrix, which are up to } 13.5 \mathrm{~cm} \text { long and } \\
1 \mathrm{~cm} \text { thick; wavy bedding is made of thin } \\
\text { (up to } 0.6 \mathrm{~cm} \text { ) muddy layers, that drape } \\
\text { the sandy ripples; nodular/lenticular bed- } \\
\text { ding is built of sandy 'lens-like' nodules } \\
\text { (up to } 15 \mathrm{~cm} \text { long and } 1.5 \mathrm{~cm} \text { thick) within } \\
\text { the muddy-sandy matrix. }\end{array}$} & \multirow{3}{*}{$\begin{array}{l}\text { Heterolithic bedding, i.e. flaser, wavy } \\
\text { and nodular/lenticular, is formed } \\
\text { when water flow changes alternative- } \\
\text { ly; sandy layers (ripples) are depos- } \\
\text { ited when water flow is relatively } \\
\text { fast (<0.5 m/s), while muddy layers } \\
\text { are deposited atop the ripples in } \\
\text { intervals of slack to almost stagnant } \\
\text { water; lowermost part of lower flow } \\
\text { regime; this association shows cyclic } \\
\text { repetition of lithofacies, which is a } \\
\text { record of waning and very low-en- } \\
\text { ergetic flow conditions; the erosive } \\
\text { surfaces are an evidence of the breaks } \\
\text { in deposition and slight erosion. }\end{array}$} \\
\hline & Sw & $\begin{array}{l}\text { fine sand } \\
\text { with a wavy } \\
\text { bedding; }\end{array}$ & & \\
\hline & STn & $\begin{array}{l}\text { silty sand } \\
\text { with a nodu- } \\
\text { lar (lenticular) } \\
\text { bedding }\end{array}$ & & \\
\hline
\end{tabular}

* - lithofacies associations only mentioned in this research; ** - lithofacies associations examined in detail.

hesive deposits (27 samples), whereas for silty-clayey, i.e. muddy, cohesive sediments ( 8 samples) the areometric method has been applied.

The classification of climbing-ripple cross-lamination used here follows Jopling \& Walker, (1968) and Allen (1973). Furthermore, the terminology of heterolithic bedding (flaser, wavy, lenticular) is that of Reineck \& Wunderlich (1968). The letter code for sediment description is a compilation of those proposed by various researchers (Miall, 1977; Ghibaudo, 1992; Zieliński, 1995), in part supplemented and modified here. For grain size the following capital letters are applied: $S$ - sand, $\mathrm{M}$ - mud, T - silt; while for sedimentary structures such lower-case letters are used: $\mathrm{m}$ - massive, $\mathrm{h}$ - horizontal, $\mathrm{r}$ - ripple, $\mathrm{rc}$ - ripple-climbing, $\mathrm{f}$ - flaser, $\mathrm{w}$ - wavy, and $\mathrm{n}$ - nodular, i.e., lenticular. The list of lithofacies recognised in the present paper is shown in Table 1. According to the codification presented herein, for example, the lithofacies code STn means silty sand with a nodular (lenticular) lamination (Table 1).

\section{Results}

The sedimentary structures that are described and interpreted below have never been observed previously within the upper Neogene fluvial channels in central Poland. To achieve the objectives of the present study, by providing indirect evidence of extremely low-energy depositional environment, first will be characterised lamination resulting from relatively faster water flow and then from the slower one. Thus, according to decreasing flow energy, they are as follows: climbing-ripple cross-lamination, flaser, wavy and lenticular bedding.

\subsection{Climbing-ripple cross-lamination}

\subsubsection{Description}

Climbing-ripple cross-lamination ( $\mathrm{rc}$ ) was documented sporadically within the palaeochannel deposits examined. In the present study two sets of climbing ripples are recognised (Fig. 3). Generally, the thickness of individual cross-strata sets is in the range of $1-2.5 \mathrm{~cm}$ and the angle of climb is less than $10^{\circ}$. The examples discussed here consist of sets of laminae that are evidently cut by erosion and individual ripples climbing one on the other. In both cases, they consist of fine sand (0.063-0.25 $\mathrm{mm})$ with an admixture of silt $(0.002-0.063 \mathrm{~mm})$, although in various proportions. This is manifested in such a way that the lamination is occasionally well visible due to the colour contrast between the more sandy and more silty laminae (Fig. 3A). On the contrary, the lamination is not clear and difficult to document photographically, when the content of grains of $<0.063 \mathrm{~mm}$ is negligible, they do not form a continuous laminae and mostly fill pores between sand grains (Fig. 3C).

\subsubsection{Interpretation}

The development of climbing-ripple cross-lamination (rc), often termed ripple drift cross-lamination, corresponds to a transition from erosional stoss to depositional stoss slopes of ripples. The examples described above (Fig. 3) represent type A of climbing-ripple structures, as distinguished by Jopling \& Walker (1968) and Allen (1973). In this case, the angle of climb is smaller than the stoss slope angle of the ripples, which means that their stoss slopes are erosional. Therefore, the lamination interpreted is also referred to as subcritical climbing-ripple cross-lamination (Hunter, 1977). 

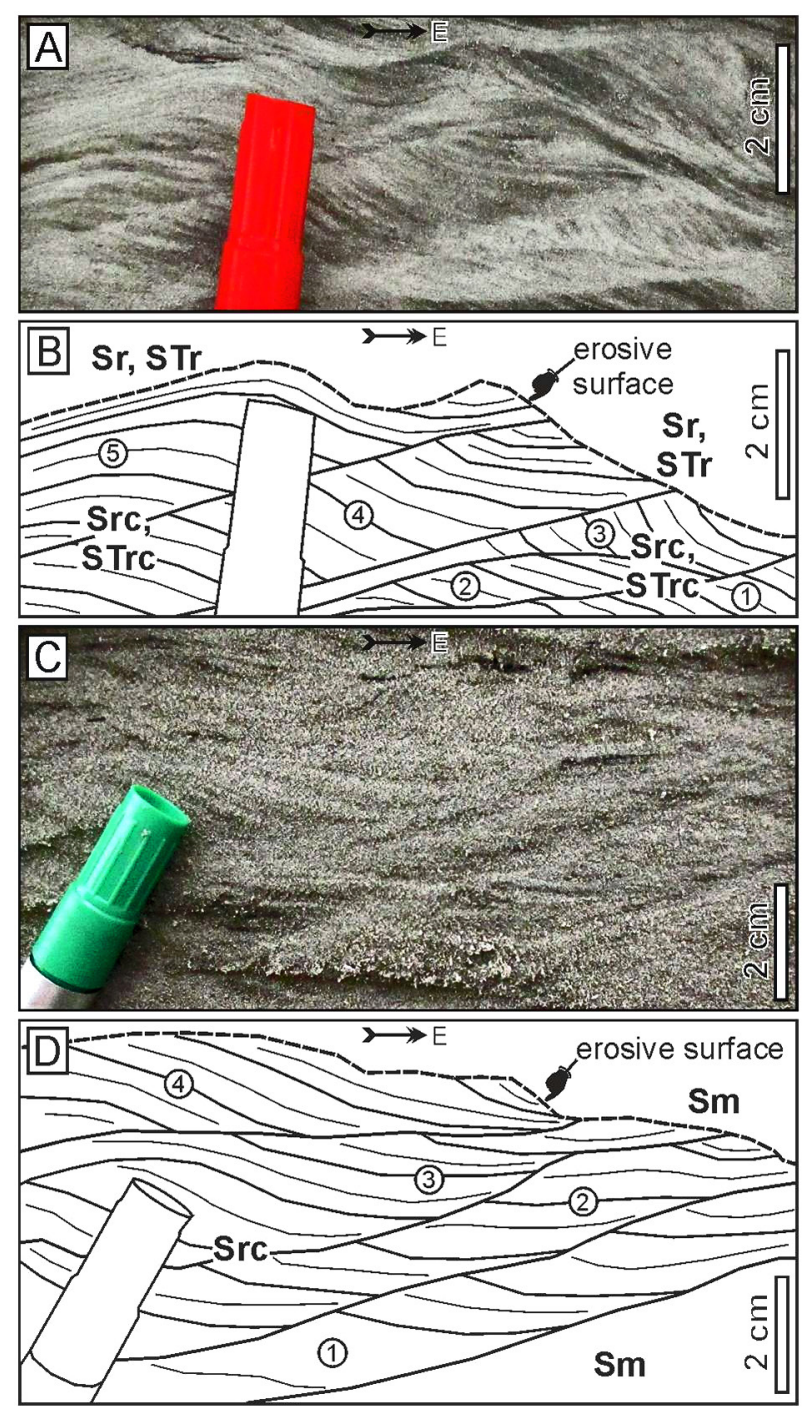

Fig. 3. Climbing-ripple cross-lamination. A, B - Sand and sandy-silt with climbing ripples; C, D - Sand with climbing ripples. Note the low angle of climb $\left(<10^{\circ}\right)$ in both examples; flow direction is from left to right, numerals in circles indicate successive generations of climbing ripples; for explanation of lithofacies code see text and Table 1

Type A ripples with erosional-stoss slopes may be formed when deposition from bedload transport exceeds suspension. Moreover, it is created when ripples receive significant supply of clastic particles from suspension (Jopling \& Walker, 1968; Allen, 1973; Ashley et al., 1982).

\subsection{Heterolithic bedding: flaser, wavy and lenticular (nodular)}

\subsubsection{Description}

Flaser bedding (f) is located in all three portions of the sedimentary succession studied (Fig. 1D);

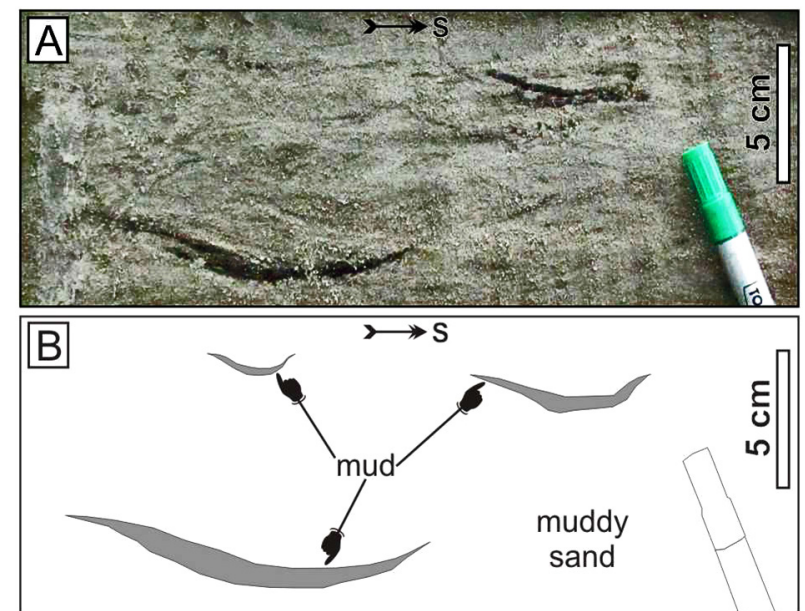

Fig. 4. Flaser bedding. Note the discontinuous muddy layers, consisting of muddy infill of ripple troughs, surrounded by poorly laminated muddy sand. Note that discontinuous 'lens-like' muddy layers surrounded by muddy sand; flow direction is almost perpendicular to the photograph; for explanation of lithofacies code see text and Table 1

however, its total thickness is negligible, i.e., $0.1-0.2$ $\mathrm{m}$ (compare Figs. 4, 7). This sedimentary structure is characterised by the presence of small lenses of mud within more coarsely grained deposits, e.g., muddy sand (Fig. 4). These muddy lenses are concave upwards, up to $13.5 \mathrm{~cm}$ in length and up to $1 \mathrm{~cm}$ in thickness and they discontinuously fill the depressions (troughs) between poorly visible ripples. They consist predominantly of mud (clay and silt $>50 \%$ ) and the rest is fine-grained sand, i.e. in the range $0.063-0.25 \mathrm{~mm}$, as laboratory analysis has shown.

Wavy bedding $(w)$ is characterised by alternating, more or less continuous thick sandy and thin muddy layers within the channel-fill deposits studied (Fig. 5). In the present paper, there are two examples of wavy lamination. The first shows the location of wavy bedding at the boundary between sandy deposits at the base and muddy sediments at the top (Fig. 5A, B). The second example presents wavy bedding that is situated within the sandy deposits (Fig. 5C, D). In both cases, the lamination described is marked by muddy layers that are more or less continuous and up to $0.6 \mathrm{~cm}$ thick. These muddy layers form a blanket that covers the sandy ripples (Fig. 5).

Lenticular, nodular bedding (n) is the commonest cross-lamination among all small-scale sedimentary structures examined in the present paper. Its thickness $(\sim 2.3 \mathrm{~m})$ covers approximately $26 \%$ of the channel-filled succession, which attains close to $9 \mathrm{~m}$ in thickness (Fig. 1D, E). This type of specif- 

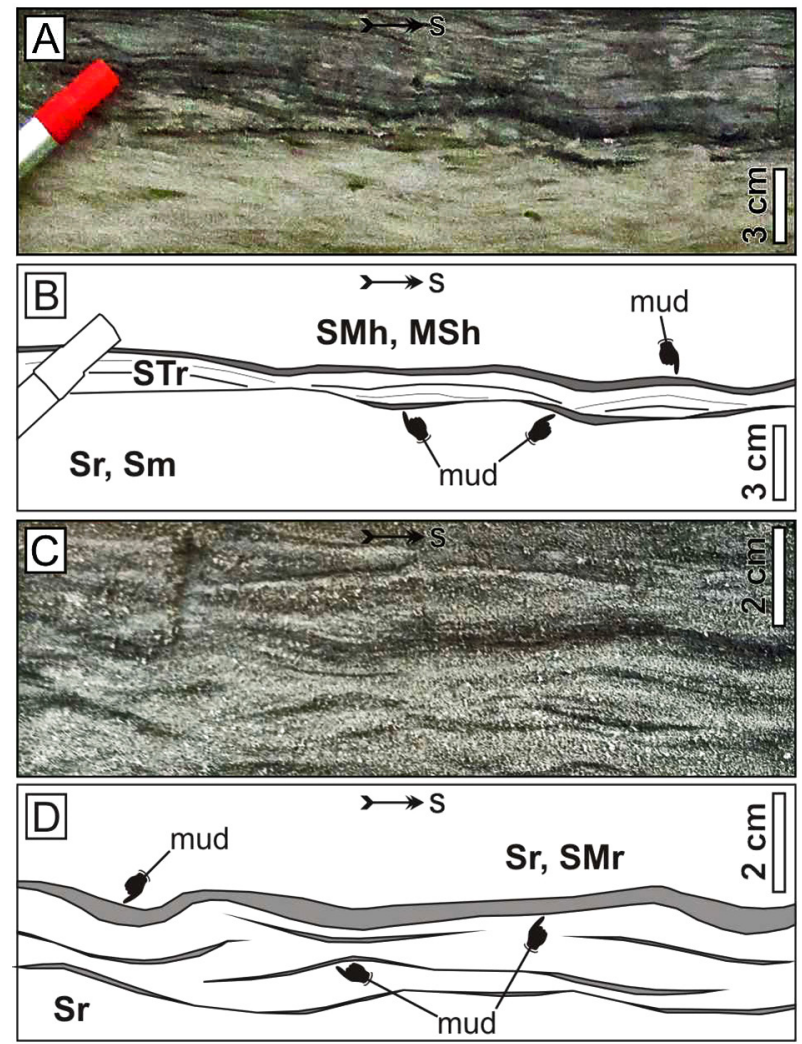

Fig. 5. Wavy bedding. A, B - wavy bedding at the boundary between the ripple cross-laminated sands and horizontally laminated muddy-sandy sediments; C, D - wavy bedding situated predominantly within rippled sandy deposits with a muddy admixture. Note the relatively continuous muddy layers that drape the sandy ripple structures; flow direction is almost perpendicular to the photograph; for explanation of lithofacies code see text and Table 1

ic lamination consists of 'lens-like' coarser-grained sediments in a matrix of finer-grained material (Fig. 6). In the present case, the lenses (nodules) consist of relatively pure, fine-grained sand, while the surrounding material consists of muddy sand. These 'lens-like', near-symmetrical structures are in fact fossilised ripples, seen parallel to the direction of their migration. The sandy nodules (lenses) are convex both upwards and downwards. Their maximum length and thickness are 15 and $1.5 \mathrm{~cm}$, respectively. These two examples, despite many similarities, differ in proportions between the sandy lenses and sandy-muddy matrix. The first example of lenticular (nodular) bedding is very close to the above-mentioned wavy lamination, because the relative proportion between lenses and their surroundings is almost equal (Fig. 6A, B). In the second example, however, the sandy-muddy matrix takes up several times more surface area than the sandy lenses of the section analysed in detail (Fig. 6C, D).
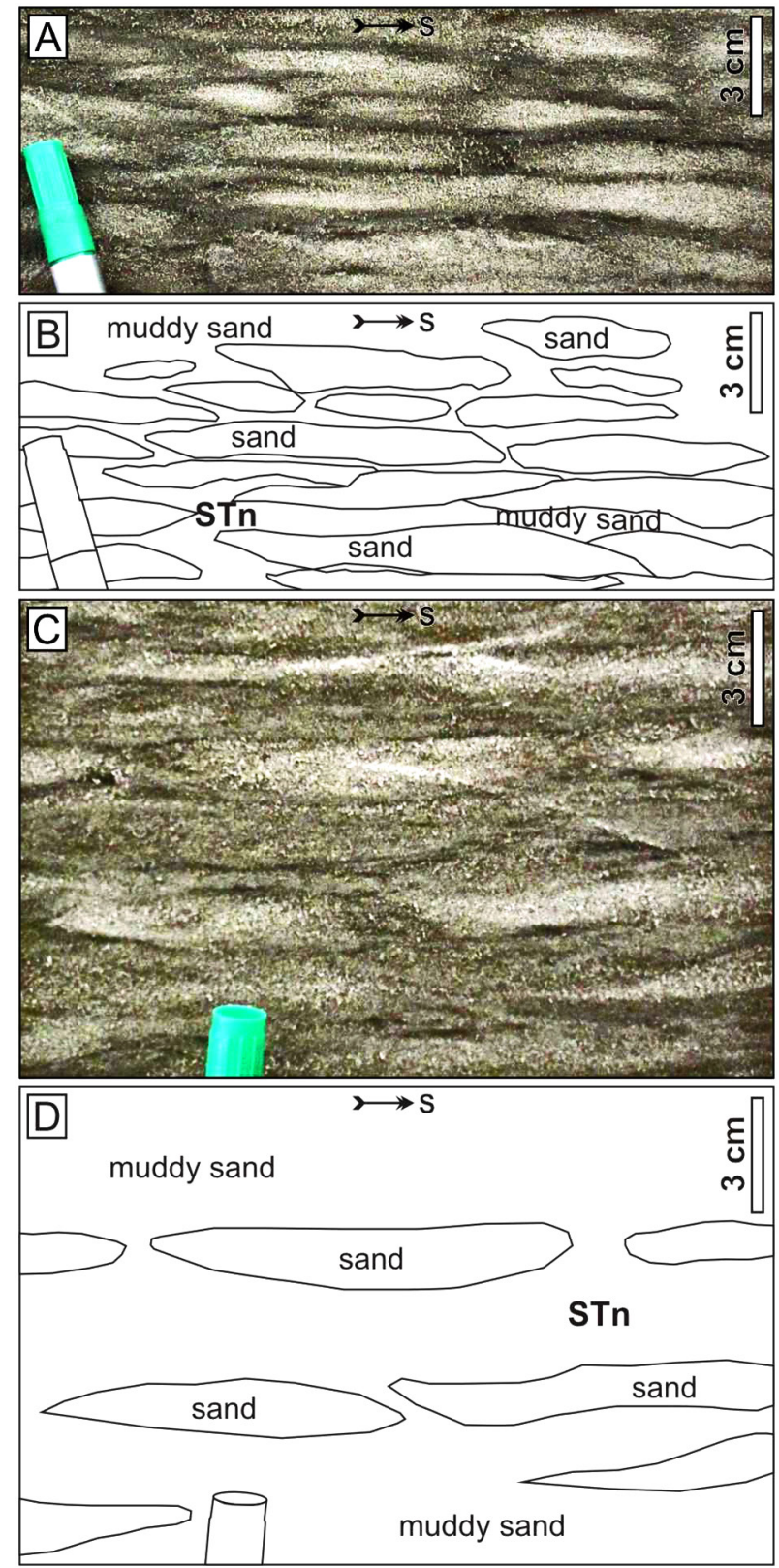

Fig. 6. Lenticular (nodular) bedding. A, B - lenticular bedding with a predominance of 'lens-like' sands; C, D - lenticular bedding with a predominance of muddy-sandy matrix. Note that 'lens-like' sands are surrounded by muddy sand; flow direction is almost perpendicular to the photograph; for explanation of lithofacies code see text and Table 1

Thus, the latter case represents typically formed lenticular bedding as originally defined by Reineck \& Wunderlich (1968).

\subsubsection{Interpretation}

Differences in the formation of various types of heterolithic lamination are related to water flow velocity and, as a result, to proportions between the 


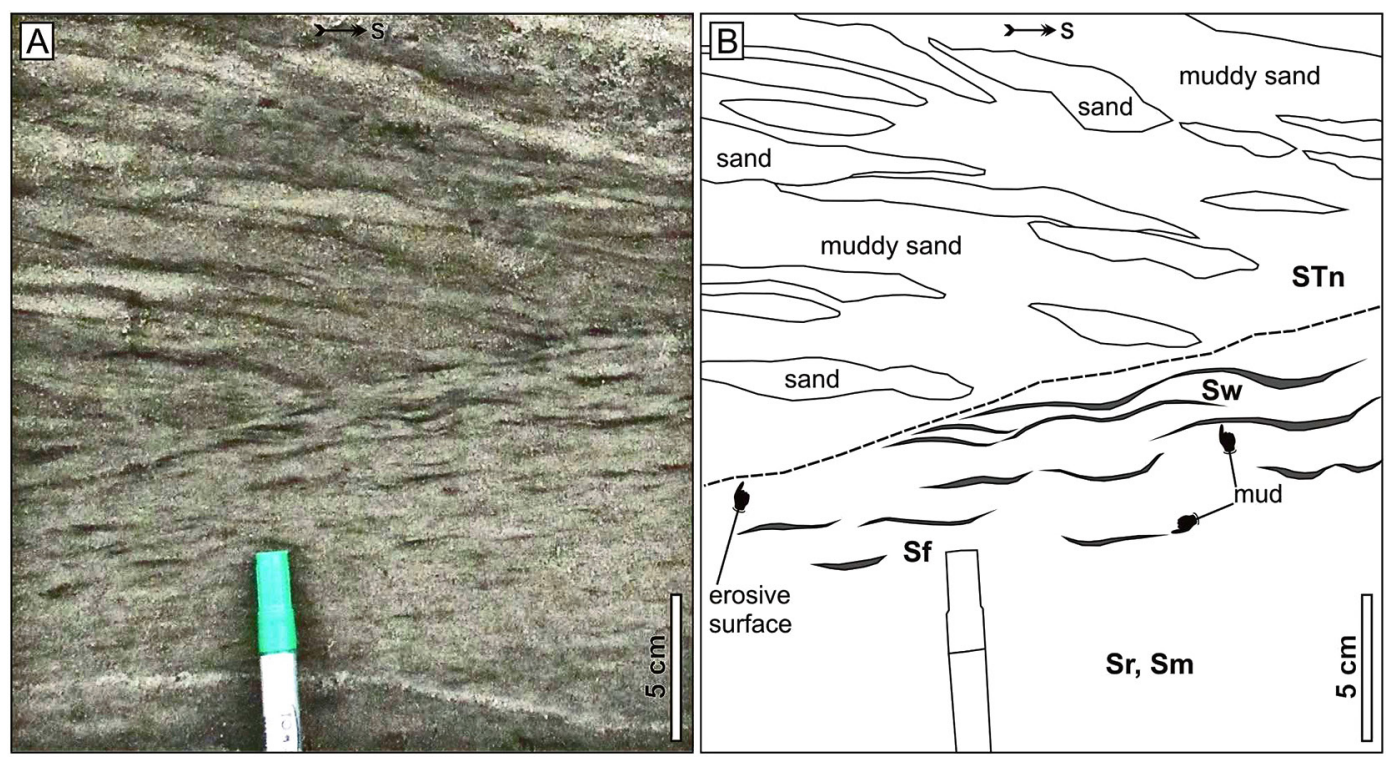

Fig. 7. Co-occurrence of various types of heterolithic bedding. Note the upward transition from flaser (Sf), through wavy (Sw) to lenticular (STn) bedding within the sedimentary succession; flow direction is almost perpendicular to the photograph; for explanation of lithofacies code see text and Table 1

amount of muddy and sandy particles deposited. Therefore, the development and preservation of the sedimentary structures interpreted may occur under alternating relatively fast and slow flow conditions. At extremely low water stages the mud is laid down predominantly from suspension, while during faster-moving water stages the sand-grained particles are deposited mainly from traction (e.g., Reineck \& Singh, 1980; Martin, 2000). However, the latest laboratory results show that flow variability is not required to produce deposits that consist of alternating muddy and sandy laminae, i.e. flaser, wavy and lenticular bedding (Baas et al., 2016). Those authors have proved that small bedforms, composed of an admixture of sand and mud and characterised by heterolithic lamination, can be generated under rapidly decelerating flows.

In the case of heterolithic bedding examples shown here, the thickness ratio of sand to mud laminae varies from more than 20 - flaser bedding (Fig. 4), through $\sim 5$ - wavy bedding (Fig. 5) to less than 1 - lenticular (nodular) bedding (Fig. 6). Additionally, an even thickness of mud layers in the case of wavy bedding (Figs. 5, 7) provides evidence that the extremely low-energy deposition was not interrupted by significant erosional events (Martin, 2000).

In contrast to the explanation given above, flaser and wavy bedding may also form simultaneously in front of larger bedforms, e.g., 2D dunes, migrating under unidirectional flow conditions (Pasierbiewicz, 1982). In this case, however, the sedimentation surface on which sandy and muddy layers were laid down in the form of lenses and/or waves, must have been originally undulated. Thus, the 'wavy' morphology of the depositional surface may be regarded as a very significant factor to influence the structural development of flaser and wavy bedding (Pasierbiewicz, 1982). In contrast, wavy cross-lamination can be formed during the final phase of the climbing process as type $\mathrm{C}$ ripples. Then, ripple migration stops and a muddy blanket atop of ripples is produced in very slow flowing or almost standing water only due to the fact that bed aggradation is caused by fallout from suspension (e.g., Jopling \& Walker, 1968; Ashley et al., 1982; Zieliński, 2014).

\section{Discussion}

The ripple-related sedimentary structures studied may be grouped into ripple to climbing-ripple cross-lamination and heterolithic bedding (Fig. 8). The first group is predominantly homolithic; hence, it is built of pure sand grains and only occasionally contains a slight admixture of finer-grained particles. In contrast, the second group of heterolithic bedding, as the name suggests, is made of lithologically different laminae, i.e., sand and mud (> 50 volume percentage of clay and silt). All of the small-scale structures tested are the result of deposition both from traction and suspension. However, climbing-ripple cross-lamination is formed when processes of traction and suspension occur at the same time (Jopling \& Walker, 1968; Allen, 1973; Hunter, 1977; Ashley et al., 1982; Allen et al., 2013). 
Fig. 8. Simplified diagram showing the relationship between traction and suspension processes, as well as between sand and mud content during formation of ripple-derived sedimentary structures. For explanation of lithofacies code see text and Table 1.

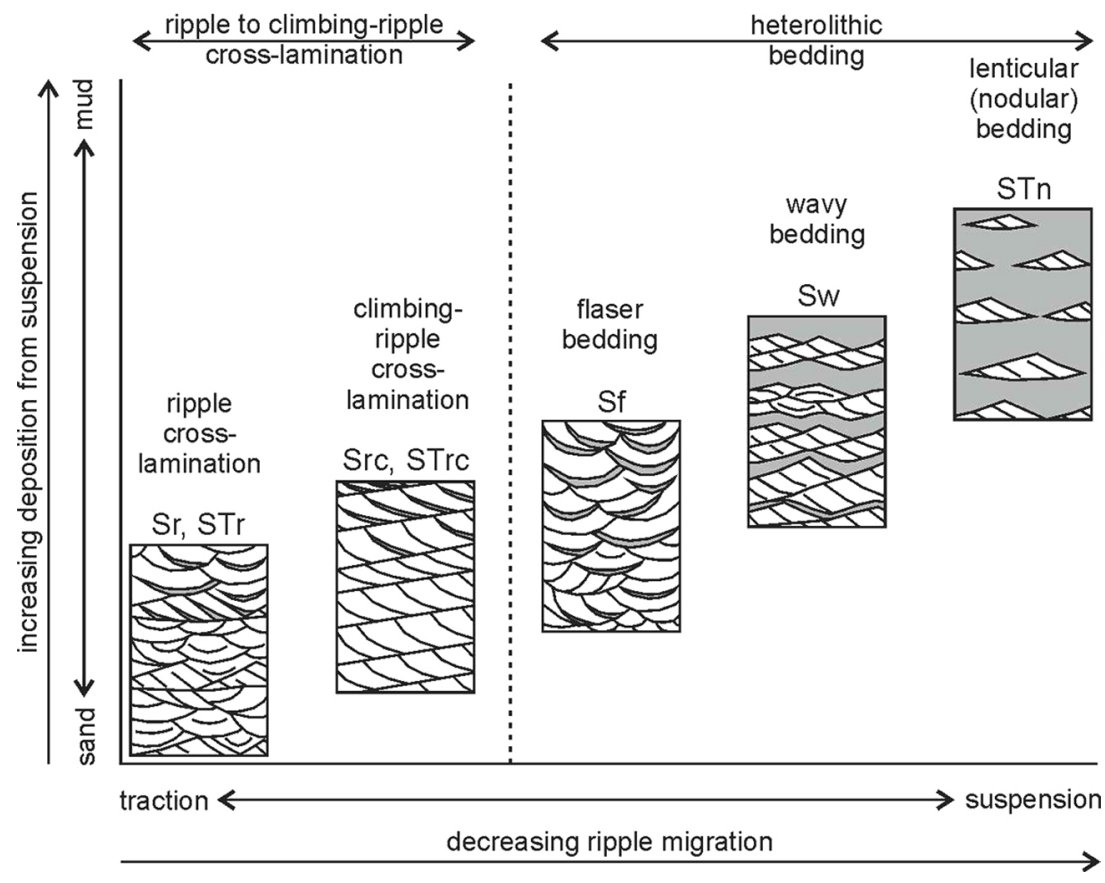

Climbing-ripple cross-lamination is formed during periods of waning flow in water that is rich in suspended sediment load. The climbing ripples studied are characterised by fine sand-grained particles, with a mean grain size of $\sim 0.2 \mathrm{~mm}$. In such a situation, fine sand is transported both in suspension and traction, when flow velocity was less than $0.5 \mathrm{~m} / \mathrm{s}$ (Baas, 1999).

In the case of heterolithic bedding (flaser, wavy, lenticular/nodular), these two processes occur alternately and/or one substantially predominates over the other (Reineck \& Singh, 1980; Yokokawa et al., 1995; Martin, 2000; Dalrymple, 2010; Fan, 2013; Kędzior, 2016). Here can be given at least two exceptions. The first exception explains the genesis of flaser and wavy lamination. Thus, under favourable flow and load conditions, these beddings can also be created simultaneously, as described above (Pasierbiewicz, 1982). The second exception is that given by Baas et al. (2016), who provided experimental evidence that the heterolithic lamination, made of an admixture of sand and mud, can be produced in rapidly decelerating flows. In the case of the late Neogene river system under investigation, this situation may have occurred, for example, when floodwaters returned to the river channels.

Heterolithic bedding does not indicate a specific depositional environment, but provides evidence of its very low energy and the presence of grains of various sizes. In addition, it proves shortterm changes from slow current to almost stagnant water. Fine sand is transported during times of a relatively faster-moving flow $(<0.5 \mathrm{~m} / \mathrm{s})$, but still very slow, and creates ripples. On the other hand, during intervals of almost stagnant water $(\sim 0 \mathrm{~m} / \mathrm{s})$ mud, i.e. clay and silt, is deposited between ripples or drapes these. Depending on the proportion between sand and mud, flaser (sand $>$ mud), wavy (sand $\approx$ mud) and lenticular/nodular (sand $<$ mud) bedding arises, respectively (Reineck \& Wunderlich, 1968; Reineck \& Singh, 1980) (Fig. 8).

The heterolithic lamination examined has been documented for the first time among upward-fining co-sets of laminae that fill the fluvial palaeochannel of late Neogene age in central Poland. Thus, flaser bedding is located at the base, wavy bedding in the middle and lenticular bedding at the top of these co-sets (compare Figs. 7, 8). This is evidence of episodic repetition of the same sedimentation cycles, which are obviously a record of a low-energy but waning flow. Such upward-fining successions may also be produced by weak storms, episodic floodings, ephemeral or intermittent streams (e.g., Reineck \& Singh, 1980; Martin, 2000; Dalrymple, 2010; Fan, 2013; Kędzior, 2016).

Considering the subdivision of fluvial systems only deposits of anastomosing channels can be characterised by water flows from flood stages to extremely low energy. The first of them are documented, among others, by deeply incised $(\sim 9 \mathrm{~m})$ the palaeochannel in muddy floodplain $-\sim 8 \mathrm{~m}$ and in lignite seam - 1 m (Fig. 1D, E) and the presence of layers with cross-lamination at various scales; however, such are beyond the scope of the present paper. On the other hand, the above-mentioned very low-energy flows are represented precisely by 
Table 2. Comparison of occurrences of climbing-ripple cross-lamination and heterolithic bedding among sediments representing various sub-environments of the main types of rivers

\begin{tabular}{|c|c|c|}
\hline River type & Sub-environments of a river & Selected references \\
\hline \multirow[t]{4}{*}{$\begin{array}{l}\text { Braided } \\
\text { (mainly sand-bed } \\
\text { braided river) }\end{array}$} & $\begin{array}{l}\text { braidplain (floodplain): } \\
\text { - common in lower parts of the sedimentary } \\
\text { successions filling flood basins }\end{array}$ & $\begin{array}{l}\text { Cant (1978), Cant \& Walker (1978), Tanner \& } \\
\text { Hubert (1992), Singh et al. (2013) }\end{array}$ \\
\hline & $\begin{array}{l}\text { braided channels: } \\
\text { - present in secondary channels during final } \\
\text { waning stages or in abandoned channels, or in } \\
\text { channel pools during low-water stages }\end{array}$ & $\begin{array}{l}\text { Rust (1978), Abdullatif (1989), Rust \& Gibling } \\
\text { (1990) }\end{array}$ \\
\hline & $\begin{array}{l}\text { - rare at tops of mid-channel bars or compound } \\
\text { bars }\end{array}$ & Doeglas (1962), Bridge \& Lunt (2006) \\
\hline & $\begin{array}{l}\text { natural levees: } \\
\text { - present in natural levees of transitional river } \\
\text { (braided-to-meandering) }\end{array}$ & Huisink (1997) \\
\hline \multirow[t]{4}{*}{ Meandering } & $\begin{array}{l}\text { meandering channels: } \\
\text { - common at uppermost parts of the abandoned } \\
\text { channel fills }\end{array}$ & $\begin{array}{l}\text { Kraus \& Middleton (1987), Kozarski et al. } \\
\text { (1988), Moskalewicz et al. (2016), }\end{array}$ \\
\hline & $\begin{array}{l}\text { - present in point-bar successions, especially at } \\
\text { their tops }\end{array}$ & Stewart (1981) \\
\hline & $\begin{array}{l}\text { crevasse splays: } \\
\text { - present in various parts of the crevasse splays }\end{array}$ & $\begin{array}{l}\text { Allen (1964), Gębica \& Sokołowski (2001), } \\
\text { Moskalewicz et al. (2016), Burns et al. (2017) }\end{array}$ \\
\hline & $\begin{array}{l}\text { natural levees: } \\
\text { - present in natural levee successions, especially } \\
\text { at their tops }\end{array}$ & $\begin{array}{l}\text { Allen (1964), Nemec (1984), Tye \& Coleman } \\
\text { (1989) }\end{array}$ \\
\hline \multirow[t]{2}{*}{ Anastomosing } & $\begin{array}{l}\text { anastomosing channels: } \\
\text { - very common at different levels in the chan- } \\
\text { nels, especially in the upper parts of successions }\end{array}$ & $\begin{array}{l}\text { Woodyer et al. (1979), Makaske }(1998,2001) \text {, } \\
\text { Gradziński et al. (2003a, b) }\end{array}$ \\
\hline & $\begin{array}{l}\text { natural levees and crevasse splays: } \\
\text { - present in these both forms }\end{array}$ & Nadon (1994), Smith \& Pérez-Arlucea (1994) \\
\hline
\end{tabular}

the specific ripple-derived sedimentary structures studied here, i.e., climbing-ripple cross-lamination and heterolithic bedding (flaser, wavy, lenticular/ nodular).

Finally, it should be noted that, in general, the occurrence of climbing ripples, but predominantly heterolithic bedding (Martin, 2000), is seldom reported from fluvial channel deposits (Table 2). In contrast, these ripple-related structures are common in the overbank zone of the sand-bed braided and meandering rivers. Therefore, the relatively high frequency of climbing-ripple and heterolithic structures, within the palaeochannel studied, is characteristic of low-energy anastomosing rivers (Table 2).

\section{Conclusions}

In 2017, due to mining activity, a palaeochannel within upper Neogene muddy deposits was exposed in the area of shallow tectonic graben in central Poland. Unexpectedly, within the channel-fill sediments, in addition to widespread massive structure and cross-lamination at various scales, appeared sandy-muddy sedimentary structures genetically related to the migration of ripples.

The structures with small-scale cross-lamination examined are characterised by climbing-ripple cross-lamination and heterolithic bedding, that is, flaser, wavy and lenticular (nodular). They formed by deposition from both traction and suspension that may have occurred simultaneously (climbing-ripple cross-lamination) or alternately (heterolithic bedding). These types of lamination are evidence of a very low-energy depositional environment, when flow velocity was from less than 0.5 $\mathrm{m} / \mathrm{s}$ to almost stagnant water, respectively.

In summary, the presence and preservation of specific ripple-derived sedimentary structures indicate that the flow in the channel changed periodically, but it was still extremely slow. The lamination studied, in particular the heterolithic bedding, formed in very slow flowing to almost stagnant water. Therefore, we believe that among the various types of rivers, only in anastomosing channels do conditions exist for the formation of ripple-derived sedimentary structures as the ones described here. 


\section{Acknowledgements}

We are indebted to the anonymous reviewers for their careful reading, critical reviews and constructive comments that helped improve a previous version of the typescript. This paper is a contribution to Research Project no. 2017/27/B/ST10/00001, funded in part by the National Science Centre, Poland.

\section{References}

Abdullatif, O., 1989. Channel-fill and sheet-flood facies sequences in the ephemeral terminal River Gash, Kassala, Sudan. Sedimentary Geology 63, 171-184.

Allen, J.P., Fielding, C.R., Rygel, M.C. \& Gibling, M.R., 2013. Deconvolving signals of tectonic and climatic controls from continental basins: an example from the late Paleozoic Cumberland Basin, Atlantic Canada. Journal of Sedimentary Research 83, 847-872.

Allen, J.R.L., 1964. A review of the origin and characteristics of recent alluvial sediments. Sedimentology 5, 89-191.

Allen, J.R.L., 1968. Current ripples: their relation to patterns of water and sediment motion. North-Holland Publishing Company, Amsterdam, 433 pp.

Allen, J.R.L., 1973. A classification of climbing ripple cross-lamination. Journal of Geological Society London 129, 537-541.

Ashley, G.M., 1990. Classification of large-scale subaqueous bedforms: a new look at an old problem. Journal of Sedimentary Petrology 60, 160-172.

Ashley, G.M., Southard, J.B. \& Boothroyd, J.C., 1982. Deposition of climbing-ripple beds: a flume simulation. Sedimentology 29, 67-79.

Baas, J.H., 1999. A flume study on the development and equilibrium morphology of current ripples in very fine sand. Sedimentology 46, 123-138.

Baas, J.H., Best, J.L. \& Peakall, J., 2016. Predicting bedforms and primary current stratification in cohesive mixtures of mud and sand. Journal of the Geological Society 173, 12-45.

Blatt, H., Middleton, G.V. \& Murray, R.C., 1980. Origin of sedimentary rocks. Prentice-Hall, Englewood Cliffs, New Jersey, 782 pp.

Bridge, J.S. \& Lunt, I.A., 2006, Depositional models of braided rivers. [In:] Sambrook Smith, G. H., Best, J.L., Bristow, C.S. \& Petts, G.E. (Eds), Braided Rivers; process, deposits, ecology and management. IAS Special Publication 36, 11-50.

Burns, C., Mountney, N.P., Hodgson, D.M., Colombera, L., 2017. Anatomy and dimensions of fluvial crevasse-splay deposits: Examples from the Cretaceous Castlegate Sandstone and Neslen Formation, Utah, U.S.A. Sedimentary Geology 351, 21-35.

Cant, D.J., 1978. Bedforms and bar types in the South Saskatchewan River. Journal of Sedimentary Petrology 48, 1321-1330.
Cant, D.J. \& Walker, R.G., 1978. Fluvial processes and facies sequences in the sandy braided South Saskatchewan River, Canada. Sedimentology 25, 625-648.

Collinson, J.D., 1970. Bedforms of the Tana River. Norway. Geografiska Annaler 52A, 31-56.

Dalrymple, R.W., 2010. Tidal depositional systems. [In:] N.P. James \& R.W. Dalrymple (Eds): Facies Models 4. Geological Association of Canada, St. John's, 201-232.

Doeglas, D.J., 1962. The structure of sedimentary deposits of braided rivers. Sedimentology 1, 167-190.

Fan, D., 2013. Classifications, sedimentary features and facies associations of tidal flats. Journal of Palaeogeography 2, 66-80.

Gębica, P. \& Sokołowski, T. 2001. Sedimentological interpretation of crevasse splays formed during the extreme 1997 flood in the upper Vistula river valley (South Poland). Annales Societatis Geologorum Poloniae 71, 53-62.

Ghibaudo, G., 1992. Subaqueous sediment gravity flow deposits: practical criteria for their field description and classification. Sedimentology 39, 423-454.

Gradziński, R., Baryła, J., Doktor, M., Gmur, D., Gradziński, M., Kędzior, A., Paszkowski, M., Soja, R., Zieliński, T. \& Żurek, S., 2003a. In-channel accretionary macroforms in the modem anastomosing system of the upper Narew River, NE Poland. Annales Societatis Geologorum Poloniae 73, 35-53.

Gradziński, R., Baryła, J., Doktor, M., Gmur, D., Gradziński, M., Kędzior, A., Paszkowski, M., Soja, R., Zieliński, T. \& Żurek, S., 2003b. Vegetation-controlled modern anastomosing system of the upper Narew River (NE Poland) and its sediments. Sedimentary Geology 157, 253-276.

Gruszka, B., 2001. Climatic versus tectonic factors in the formation of the glaciolacustrine succession (Bełchatów outcrop, central Poland). Global and Planetary Change 28, 53-71.

Gruszka, B., Morawski, W. \& Zieliński, T., 2012. Sedimentary record of a Pleistocene ice-sheet interlobate zone (NE Poland). Geologos 18, 65-81.

Hadlari, T., Rainbird, R.H. \& Donaldson, J.A., 2006. Alluvial, eolian and lacustrine sedimentology of a Paleoproterozoic half-graben, Baker Lake Basin, Nunavut, Canada. Sedimentary Geology 190, 47-70.

Huisink, M., 1997. Late-glacial sedimentological and morphological changes in a lowland river in response to climatic change: the Maas, S Netherlands. Journal of Quaternary Science 12, 209-223.

Hunter, R.E., 1977. Terminology of cross-stratified sedimentary layers and climbing-ripple structures. Journal of Sedimentary Petrology 47, 697-706.

Jopling, A.V \& Walker, R.G., 1968. Morphology and origin of ripple drift cross-lamination, with examples from the Pleistocene of Massachusetts. Journal of Sedimentary Petrology 38, 971-984.

Kasiński, J.R. \& Słodkowska, B., 2016. Factors controlling Cenozoic anthracogenesis in the Polish Lowlands. Geological Quarterly 60, 959-974.

Kędzior, A., 2016. Reconstruction of an early Pennsylvanian fluvial system based on geometry of sandstone bodies and coal seams: the Zabrze Beds of the Up- 
per Silesia Coal Basin, Poland. Annales Societatis Geologorum Poloniae 86, 437-472.

Kozarski, S., Gonera, P. \& Antczak, B., 1988. Valley floordevelopment and paleohydrological change: The Late Vistulian and Holocene history of the Warta River (Poland). [In:] G. Lang \& C. Schlüchter (Eds): Lake, Mire and River Environments. Balkema, Rotterdam, 185-203 pp.

Kraus, M.J. \& Middleton, L.T., 1987. Dissected paleotopography and base-level changes in a Triassic fluvial sequence. Geology 15, 18-21.

La Croix, A.D. \& Dashtgard, S.E., 2015. A synthesis of depositional trends in intertidal and upper subtidal sediments across the tidal-fluvial transition in the Fraser River, Canada. Journal of Sedimentary Research 85, 683-698.

Lundegard, P.D. \& Samuels, N.D., 1980. Field classification of fine-grained sedimentary rocks. Journal of Sedimentary Petrology 50, 781-786.

Makaske, B., 1998. Anastomosing Rivers: Forms, Processes and Sediments. Netherlands Geographical Studies 249, University of Utrecht, $287 \mathrm{pp}$.

Makaske, B., 2001. Anastomosing rivers: a review of their classification, origin and sedimentary products. Earth-Science Reviews 53, 149-196.

Martin, A.J., 2000. Flaser and wavy bedding in ephemeral streams: a modern and an ancient example. Sedimentary Geology 136, 1-5.

Miall, A.D., 1977. A review of the braided-river depositional environment. Earth-Science Reviews 13, 1-62.

Moskalewicz, D., Sokołowski, R.J. \& Fedorowicz, S., 2016. River response to climate and sea level changes during the Late Saalian/Early Eemian in northern Poland - a case study of meandering river deposits in the Chłapowo cliff section. Geologos 22, 1-14.

Nadon, G.C., 1994. The genesis and recognition of anastomosed fluvial deposits: data from the St. Mary River Formation, southwestern Alberta, Canada. Journal of Sedimentary Research 64, 451-463.

Nemec, W., 1984. Warstwy wałbrzyskie (dolny namur) w Zagłębiu Wałbrzyskim: analiza aluwialnej sedymentacji w basenie węglowym [Wałbrzych Beds (Lower Namurian, Wałbrzych Coal Basin): analysis of alluvial sedimentation in a coal basin]. Geologia Sudetica 19, 7-73.

Pasierbiewicz, K.W., 1982. Experimental study of cross-strata development on an undulatory surface and implications relative to the origin of flaser and wavy bedding. Journal of Sedimentary Petrology 52, 769-778.

Pawłowski, D., Gruszka, B., Gallas, H. \& Petera-Zganiacz, J., 2013. Changes in the biota and sediments of glacial Lake Koźmin, Poland, during the late Saalian (Illinoian). Journal of Paleolimnology 49, 679-696.

Piwocki, M. \& Ziembińska-Tworzydło, M., 1997. Neogene of the Polish Lowlands - lithostratigraphy and pollen-spore zones. Geological Quarterly 41, 21-40.

Rust, B.R., 1978. A classification of alluvial channel systems. [In:] Miall, A.D. (Ed.), Fluvial Sedimentology. Canadian Society of Petroleum Geologists Memoir 5, Calgary, 187-198.
Rust, B.R. \& Gibling, M.R., 1990. Three-dimensional antidunes as HCS mimics in a fluvial sandstone; the Pennsylvanian South Bar Formation near Sydney, Nova Scotia. Journal of Sedimentary Petrology 60, 540-548.

Reineck, H.E. \& Singh, I.B., 1980. Depositional Sedimentary Environments. Springer-Verlag, Berlin, 549 pp.

Reineck, H.E. \& Wunderlich, F., 1968. Classification and origin of flaser and lenticular bedding. Sedimentology 11, 99-104.

Singh D.S., Kumar S., Kumar D., Awasthi, A. \& Bhardwaj, V., 2013. Sedimentology and Channel Pattern of the Chhoti Gandak River, Ganga Plain, India. Gondwana Geological Magazine 28, 171-180.

Smith, N.D. \& Pérez-Arlucea, M., 1994. Fine-grained splay deposition in the avulsion belt of the lower Saskatchewan River, Canada. Journal of Sedimentary Research B 64, 159-168.

Stewart, D.J., 1981. A meander-belt sandstone of the Lower Cretaceous of S England. Sedimentology 28, 1-20.

Środoń, J., 1974. An interpretation of climbing-ripple cross-lamination. Annales Societatis Geologorum Poloniae 44, 449-473.

Tanner, L.H. \& Hubert, J.F., 1992. Depositional facies, paleogeography and palaeoclimatology of the Lower Jurassic McCoy Brook Formation, Fundy rift basin, Nova Scotia. Palaeogeography, Palaeoclimatology, Palaeoecology 96, 261-280.

Tye, R.S. \& Coleman, J.M., 1989. Evolution of Atchafalaya lacustrine deltas, south-central Louisiana. Sedimentary Geology 65, 95-112.

Widera, M., 2007. Litostratygrafia i paleotektonika kenozoiku podplejstoceńskiego Wielkopolski [Lithostratigraphy and palaeotectonics of the sub-Pleistocene Cenozoic of Wielkopolska]. Adam Mickiewicz University Press, Poznań, 224 pp.

Widera, M., 2012. Fluwialna geneza ogniwa wielkopolskiego na podstawie danych z obszaru środkowej Polski [Fluvial origin of the Wielkopolska Member based on data from the central Poland]. Górnictwo Odkrywkowe 53, 109-118.

Widera, M., 2013. Sand- and mud-filled fluvial palaeochannels in the Wielkopolska Member of the Neogene Poznań Formation, central Poland. Annales Societatis Geologorum Poloniae 83, 19-28.

Widera, M., 2014. Lignite cleat studies from the first Middle-Polish (first Lusatian) lignite seam in central Poland. International Journal of Coal Geology 131, 227-238.

Widera, M., 2016a. Depositional environments of overbank sedimentation in the lignite-bearing Grey Clays Member: New evidence from Middle Miocene deposits of central Poland. Sedimentary Geology 335, 150-165.

Widera, M., 2016b. An overview of lithotype associations forming the exploited lignite seams in Poland. Geologos 22, 213-225.

Widera, M., Kowalska, E. \& Fortuna, M., 2017. A Miocene anastomosing river system in the area of Konin Lignite Mine, central Poland. Annales Societatis Geologorum Poloniae 87, 157-168.

Woodyer, K.D., Taylor, G. \& Crook, K.A.W., 1979. Depositional processes along a very low-gradient suspend- 
ed-load stream: the Barwon River, New South Wales. Sedimentary Geology 22, 97-120.

Yokokawa, M., Kishi, M., Masuda, F. \& Yamanaka, M., 1995. Climbing ripples recording the change of tidal current condition in the middle Pleistocene Shimosa Group, Japan. Special Publication of the International Association of Sedimentologists 24, 301-311.

Zieliński, T., 1995. Kod litofacjalny i litogenetyczny - konstrukcja i zastosowanie [Lithofacies and lithogenetic code - construction and application] [In:] E. Mycielska-Dowgiałło \& J. Rutkowski (Eds): Badania osadów czwartorzędowych. Wybrane metody $i$ interpretacja wyników [Investigation of Quaternary deposits. Results of some methods and interpretations]. Warsaw University Press, Warsaw, 220-235.

Zieliński, T., 2014. Sedymentologia: Osady rzek i jezior [Sedimentology. River and lake deposits]. Adam Mickiewicz University Press, Poznań, 594 pp.

Zieliński, T. \& van Loon, A.J., 2000. Subaerial terminoglacial fans III: overview of sedimentary characteristics and depositional model. Geologie en Mijnbouw/Netherlands Journal of Geosciences 79, 93-107.

Manuscript received: 27 August 2018 Revision accepted: 28 November 2018 